\title{
PENINGKATAN PEREKONOMIAN RUMAH TANGGA MISKIN MELALUI FASILITASI INKUBASI USAHA MANDIRI PADA WARGA RUMAH SUSUN DUPAK BANDAREJO
}

\author{
Rodhiyah, Pujianto \\ Universitas Wijaya Putra \\ email : rodiah11@yahoo.co.id
}

\begin{abstract}
Abstrak
Program ini bekerjasama Pemerintah Kota Surabaya dalam upaya penanggulangan kemiskinan berbasis pemberdayaan adalah melalui pelatihan keterampilan dasar bagi keluarga miskin. Tujuan program ini adalah untuk pemberdayaan masyarakat yang tinggal di rumah susun, meningkatkan ketrampilan usaha mandiri masyarakat penghuni rumah susun dan menambah penghasilan masyarakat penghuni rumah susun. Permasalahan yang dihadapi mitra antara lain: rendahnya motivasi berwirausaha, belum memiliki keterampilan wirausaha, pengelollan keuangan yang buruk dan rendahnya kemampuan pemasaran. Metode pelaksanaan program adalah melalui Identifikasi melalui survey pengumpulan data calon peserta pemberdayaan pelatihan, penyuluhan Motivasi Dan Pembentukan Kelompok Usaha Bersama, Pelatihan Ketrampilan Produksi, Pelatihan Manajemen Usaha, dan Pendampingan Manajemen Usaha. Hasil Pelaksanaan program antara lain; Pelatihan Motivasi Wirausaha, Pelatihan Keterampilan, Pelatihan Manajemen Pemasaran, Pelatihan Manajemen Keuangan, Pelatihan Manajemen Organisasi dan SDM, Penyuluhan Legalitas Usaha dan Lingkungan, dan Penyuluhan Akses Permodalan. Kemudian dilanjutkan dengan pendampingan yang memfasilitasi peserta agar dapat konsultasi terkait hasil mereka mempraktekkan ilmu yang sudah diberikan pada beberapa pelatihan sebelumnya. Disamping menerima konsultasi para narasumber pendampingan juga memberikan tips dan trik untuk mengatasi permasalahan-permasalahan yang dihadapi peserta.
\end{abstract}

Kata Kunci : Masyarakat Miskin Perkotaan, Inkubasi Usaha Mandiri

\section{PENDAHULUAN}

Surabaya merupakan kota Metropolitan terbesar kedua di Indonesia yang memiliki magnet penarik bagi penduduk daerah penyangga terutama wilayah perdesaan di sekitarnya. Seiring waktu, dengan makin bertambahnya jumlah penduduk alami dan pendatang maka Surabaya menjadi kota yang sangat padat dan bermunculanlah perkampungan kumuh dan kebutuhan untuk perumahan kian meningkat. Menurut data Pemkot Surabaya, kebutuhan lahan perumahan tahun 20013-2013 mencapai $17.593 \mathrm{Ha}$
(53,8\% dari total luas Surabaya) dengan jumlah kebutuhan permukiman mencapai 556.542 unit. Pembangunan rumah susun sebagai alternative hunian bagi masyarakat berpenghasilan rendah telah dilaksanakan oleh Pemkot Surabaya beberapa tahun terakhir. Namun demikin keberadaan rusun paska huni cenderung menjadi kumuh dan menambah kekumuhan lingkungan. Oleh karenanya terdapat dua kebijakan terkait yang kini dilaksanakan yaitu pembangunan kembali rusun dengan konsep redevelopment dan kerjasama dengan kementerian untuk pemberdayaan masyarakat di kampung Ekonomi, Sosial dan Budaya

1451 
kumuh. Program pemberdayaan masyarakat melalui pelatihan keterampilan dasar merupakan program pemberdayaan dengan bentuk pelatihan keterampilan dasar yang terbagi menjadi beberapa jenis pelatihan dasar yang dilaksanakan. Dalam pelaksanaannya juga terdapat mekanisme operasional yang tertuang dalam pedoman pelaksanaan pemberdayaan ekonomi bagi keluarga miskin.

Pemerintah Kota Surabaya merupakan salah satu Kota yang melaksanakan program penanggulangan kemiskinan dengan berbasis pemberdayaan masyarakat dalam peningkatan kualitas hidup masyarakatnya. Rancangan pemberdayaan masyarakat ini didesain sebagai pengembangan potensi yang dimiliki oleh kelompok masyarakat miskin dan kemampuan potensi yang dimiliki oleh para stakeholders seperti organisasi pemerintah, organisasi non-pemerintah, dan masyarakat itu sendiri. Salah satu program Pemerintah Kota Surabaya dalam upaya penanggulangan kemiskinan berbasis pemberdayaan adalah melalui pelatihan keterampilan dasar bagi keluarga miskin.

Dinas Pengendalian Penduduk, Pemberdayaan Perempuan dan Perlindungan Anak sebagai salah satu SKPD yang bertanggung jawab dalam pemberdayaan masyarakat bermaksud mengadakan pelatihan ketrampilan dasar bagi penghuni rusun. Pelatihan keterampilan dasar bagi keluarga miskin merupakan salah satu program penanggulangan kemiskinan dengan memberdayakan masyarakat dalam meningkatkan ketahanan ekonomi keluarga yang tinggal di rusun di Kota Surabaya. Selain itu,, pelatihan keterampilan dasar bagi keluarga rusun ini juga bertujuan untuk dapat meningkatkan tumbuhnya kelompok-kelompok usaha baru di lingkungan rusun. Dalam pelaksanaannya, Para peserta dalam program pelatihan keterampilan dasar akan diberi bekal pelatihan dan juga akan mendapatkan pendampingan sehingga para peserta pelatihan keterampilan dasar akan tergabung dalam kelompok swadaya masyarakat (KSM) yang kemudian akan mendapatkan pendampingan serta bantuan peralatan kerja dan fasilitasi pemasaran agar bisa berproduksi dan memasarkan produknya secara mandiri.

Program ini dimaksudkan untuk implementasi Program Pemberdayaan Masyarakat Kota Surabaya dengan Kegiatan Fasilitasi Inkubasi Usaha Mandiri bagi penghuni Rumah Susun Dupak Bangunrejo dan penghuni Rumah Susun Romokalisari di Kota Surabaya. Sedangkan tujuan dari program ini adalah; 1) Pemberdayaan masyarakat yang tinggal di rumah susun; 2). Meningkatkan ketrampilan usaha mandiri masyarakat penghuni rumah susun; dan 3) Menambah penghasilan masyarakat penghuni rumah susun.

\section{METODE}

Metode pelaksanaan kegiatan ini antara lain; 1). Identifikasi, meliputi kegiatan survey pengumpulan data calon peserta pemberdayaan pelatihan; 2). Penyuluhan Motivasi Dan Pembentukan Kelompok Usaha Bersama, meliputi kegiatan Open Mind tentang Manfaat dan Keuntungan memiliki Usaha sendiri, dilanjutkan dengan testimoni pengalaman dari wirausahawan yang berhasil hasil binaan DP5a dan diakhiri dengan pembentukan kelompok usaha bersama; 3). Pelatihan Ketrampilan Produksi, meliputi kegiatan pelatihan ketrampilan usaha produksi, sesuai bidang usaha yang diminati oleh peserta; 4). Pelatihan Manajemen Usaha, meliputi kegiatan pelatihan manajemen usaha, dalam bidang manajemen pemasaran, manajemen organisasi \& SDM, manajemen, manajemen keuangan, penyuluhan legalitas usaha dan lingkungan serta penyuluhan akses permodalan; dan 5). Pendampingan Manajemen Usaha, meliputi kegiatan pendampingan manajemen produksi, manajemen pemasaran dan manajemen keuangan

\section{HASIL DAN PEMBAHASAN}

\section{Program Fasilitasi Inkubasi Usaha Mandiri}

Program Fasilitasi Inkubasi Usaha Mandiri pesertanya berasal dari Rusun Dupak Bangunrejo dan Rusun Pesapen. Peserta yang mendaftar lebih kurang 40 Orang penghuni Rusun Dupak bangunrejo dan Pesapen. Program Fasilitasi Inkubasi ini disosialisasikan kepada warga Rusun Dupak pada tanggal 1 Oktober 2017 yang dihadiri oleh Perwakilan dari DP5A dan Tim BEDRC Universitas Wijaya Putra Surabaya.

$$
\text { Ekonomi, Sosial dan Budaya }
$$


Program Fasilitasi Inkubasi Usaha Mandiri ini terdiri dari kegiatan beberapa pelatihan dan pendampingan - pendampingan . adapun beberapa pelatihan yang akan diberikan kepada peserta terdapat tujuh jenis pelatihan yaitu : 1) Pelatihan Motivasi Wirausaha; 2). Pelatihan Keterampilan; 3). Pelatihan Manajemen Pemasaran; 4). Pelatihan Manajemen Keuangan; 5). Pelatihan Manajemen Organisasi dan SDM; 6). Penyuluhan Legalitas Usaha dan Lingkungan; dan 7). Penyuluhan Akses Permodalan.

Setelah rangkaian pelatihan selesai kemudian dilanjutkan dengan pendampingan. Pendampingan ini memfasilitasi peserta agar dapat konsultasi terkait hasil mereka mempraktekkan ilmu yang sudah diberikan pada beberapa pelatihan sebelumnya. Disamping menerima konsultasi para narasumber pendampingan juga memberikan tips dan trik untuk mengatasi permasalahanpermasalahan yang dihadapi peserta. Adapun jenis pendampingan yaitu : 1). Pendampingan Manajemen Produksi; 2. Pendampingan Manajemen Pemasaran; 3. Pendampingan Manajemen Keuangan; 4. Pendampingan SDM; 5. Pendampingan Legalitas Usaha;6. Pendampingan Lingkungan; dan 7. Pendampingan Akses Permodalan

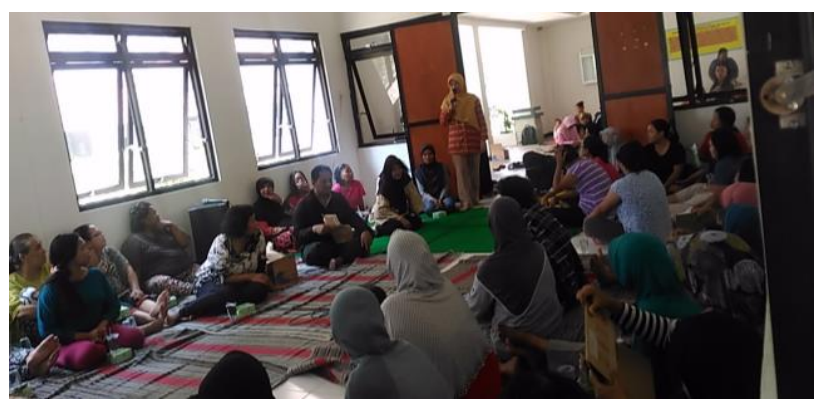

Gambar 1 Pembukaan Fasilitasi Inkubasi Usaha Mandiri di Rusun Romokalisari

\section{Pelatihan Fasilitasi Inkubasi Usaha Mandiri}

Pelatihan Fasilitasi Inkubasi Usaha Mandiri ini diadakan di Rusun Dupak Bangunrejo. Peserta Pelatihan di Rusun Dupak Bangunrejo adalah ibu-ibu penghuni Rusun Dupak Bangunrejo dan ibu-ibu penghuni Rusun Pesapen yang telah mendaftar pada program Fasilitasi Inkubasi Usaha Mandiri.

\section{Pelatihan Motivasi Wirausaha (Opend Mind)}

Pelatihan Motivasi Wirausaha merupakan pelatihan yang bertujuan untuk menstimulus munculnya minat untuk berwirausaha. Pelatihan ini bersifat Open Mind yaitu mengedukasi peserta agar memiliki pikiran lebih terbuka terhadap peluangpeluang meningkatkan penghasilan keluarga melalui berwirausaha. Selain penyampaian materi motivasi didukung juga oleh Kesaksian (Testimoni) dari Ibu yang sudah sukses berwirausaha meskipun memulai usaha tanpa memiliki modal yang mencukupi dan akhirnya usahanya dapat berkembang dan sukses.

Pelatihan Motivasi Wirausaha dimulai dengan Materi Motivasi Wirausaha "Mengungkap Rahasia Berwirausaha dengan Cara Termudah dan Menghasilkan Bagi Ibu-Ibu Rusun Romokalisari" yang disampaikan oleh Ibu Karlin, SE, M.Ak selaku narasumber.

Kesaksian (Testimoni) Wirausaha Sukses disampaikan oleh $\mathrm{Bu}$ Sudarwi Ningsih dan $\mathrm{Bu}$ Sutinem. Bu Sudarwi Ningsih merupakan Pengusaha Brownies Kering, Egg Roll dan aneka Kue Kering lainnya yang memulai usaha karena terbelit hutang puluhan juta akibat melahirkan anak kembar prematur. Sementara Bu Sutinem adalah pengusaha Kerupuk Aneka Rasa yang memulai usaha karena ingin meningkatkan perekonomian keluarga hanya bermodal sebuah singkong hasil minta kepada petani yang dijadikan modal untuk membuat kerupuk samiler.

Setelah peserta mendapatkan motivasi dan mendengarkan cerita kesaksian Bu Sudarwi Ningsih dan $\mathrm{Bu}$ Sutinem, peserta segera diajak untuk berperan aktif dalam program inkubasi ini. Pengenalan Program disampaikan oleh Bapak Andi Iswoyo, SE, MM selaku narasumber. Kemudian dilanjutkan dengan pembentukan kelompok sesuai dengan minat usaha yang dipilih oleh peserta yaitu Usaha Brownies Kering atau Kerupuk Aneka Rasa (Kerupuk Samiler).

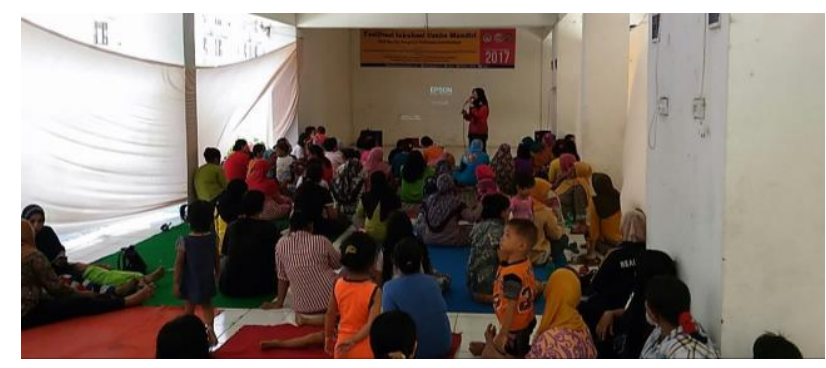


Gambar 2 Pelatihan Open Mind - Testimoni di Rusun Dupakbangunrejo

\section{Pelatihan Keterampilan Brownies Kering dan Kerupuk Aneka Rasa}

Pelatihan Keterampilan bertujuan agar peserta memiliki keterampilan yang dapat dijadikan usaha mandiri. Pelatihan Keterampilan ini mengajarkan untuk membuat Brownies Kering dan Kerupuk Aneka Rasa (Samiler). Peserta mengikuti kelas pelatihan sesuai dengan peminatan yang telah dipilih sebelumnya.

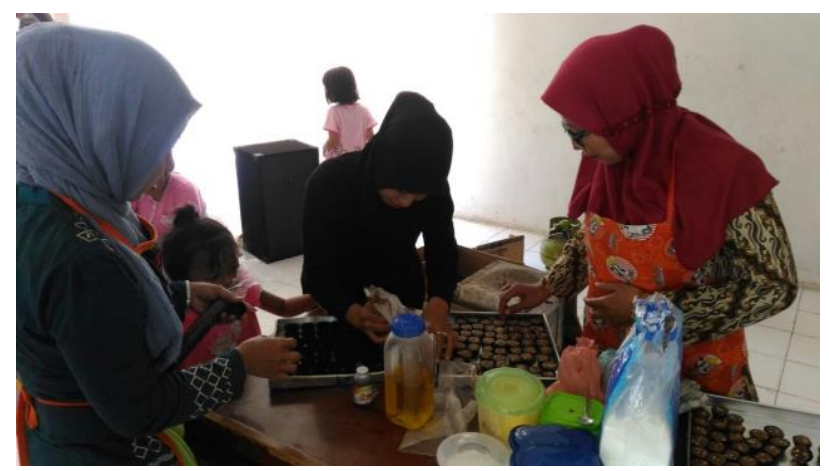

Gambar 3 Pelatihan Keterampilan Membuat Brownies Kering di Rusun Romokalisari

\section{Pelatihan Manajemen Pemasaran}

Pelatihan Manajemen Pemasaran dengan judul "Cara Memasarkan Produk Agar Laris Manis". Pelatihan Manajemen Pemasaran ini bertujuan untuk mengedukasi peserta pelatihan agar memahami cara melakukan pemasaran secara baik dan benar. Kemampuan untuk melakukan pemasaran merupakan salah satu bagian penting dalam wirausaha.

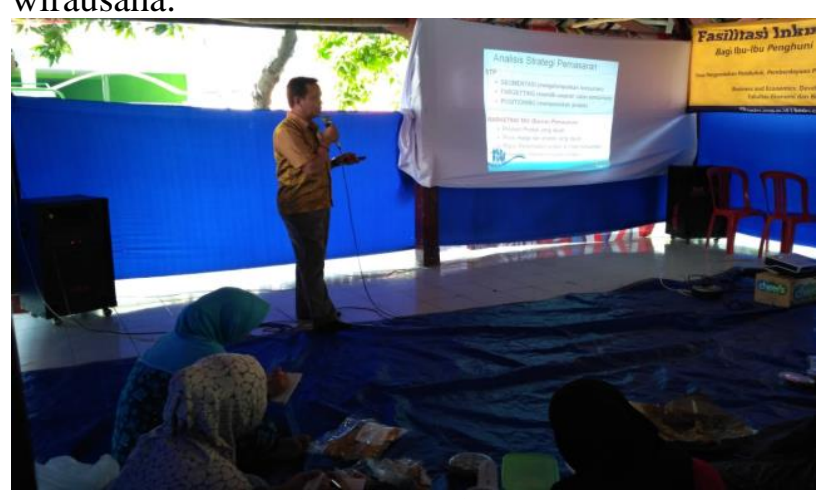

Gambar 4 Pelatihan Manajemen Pemasaran di Rusun Dupak

\section{Pelatihan Manajemen Keuangan}

Pelatihan Manajemen Keuangan dengan judul "Cara Menghitung Biaya, Menentukan Harga dan Menghindari Kerugian Usaha Agar Selalu Untung". Peserta mendapat engetahuan dasar tentang manjemen keuangan sehingga peserta mampu menentukan harga jual produknya, mampu melakukan pencatatan sederhana dan dapat menghitung keuntungannya.

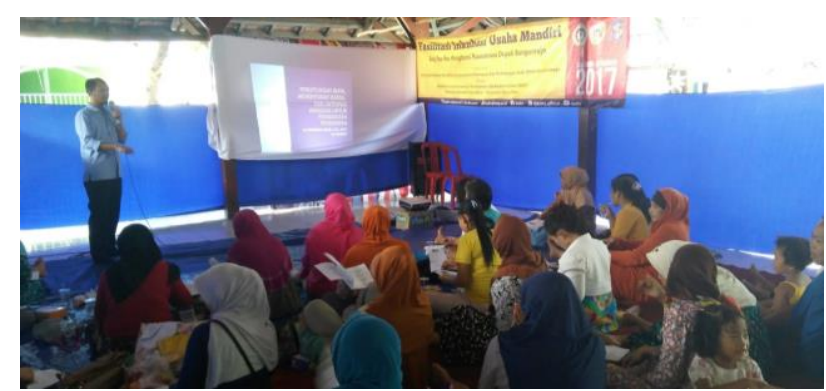

Gambar 5 Pelatihan Manajemen Keuangan di Rusun Dupak

\section{Pelatihan Manajemen Organisasi dan SDM}

Pelatihan Manajemen Organisasi dan SDM dengan judul "Kerja Santai Berkualitas" merupakan pelatihan yang bertujuan agar peserta mampu membagi tugas anggota kelompok dan masingmasing mampu menjalankan tugasnya dengan baik tanpa merasa iri dengan anggota lain. Apabila omset terus meningkat dan mereka butuh untuk mempekerjakan orang lain untuk membantu produksi atau pemasaran, diharapkan mampu mengorganisir orang yang dipekerjakan tersebut dengan baik.

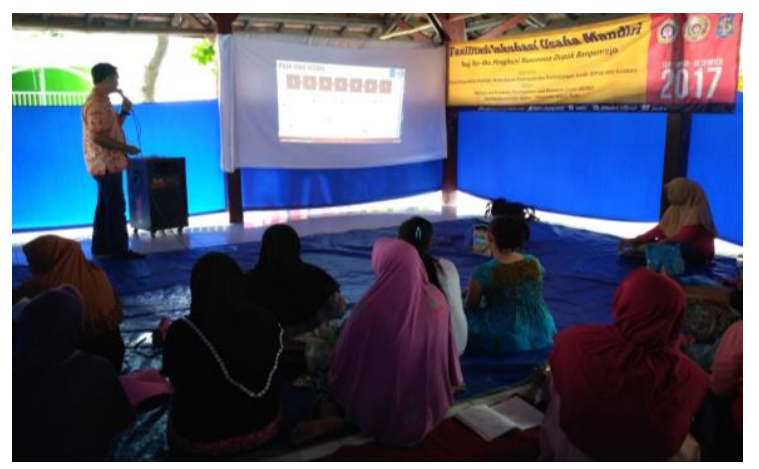

Gambar 6 Pelatihan Manajemen Organisasi dan SDM di Rusun Dupak

Ekonomi, Sosial dan Budaya 


\section{Penyuluhan Legalitas Usaha dan Lingkungan}

Penyuluhan Legalitas Usaha dan Lingkungan merupakan edukasi bagi peserta untuk mengetahui cara memgurus perijinan atau legalitas bagi produk yang telah diproduksi oleh peserta pelatihan. Legalitas sangat penting untuk mengembangkan usaha agar tidak terkendala saat dipasarkan ke wilayah yang lebih luas

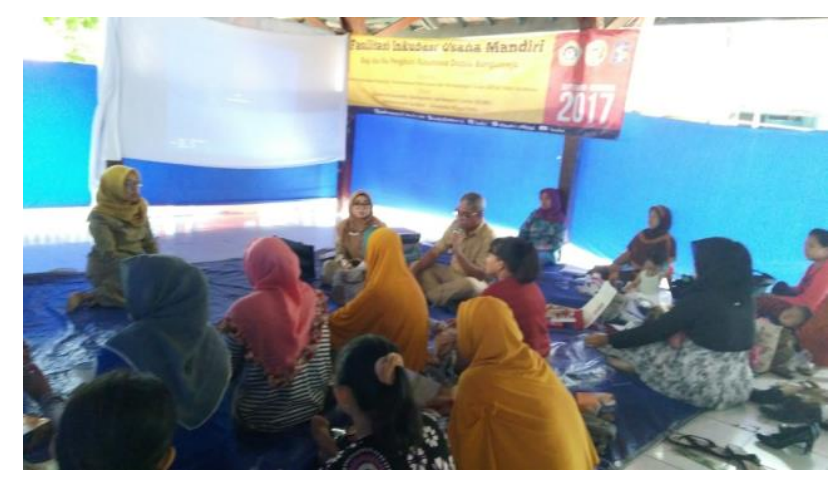

Gambar 7 Penyuluhan Legalitas Usaha dan Lingkungan di Rusun Romokalisari

\section{Penyuluhan Akses Permodalan}

Penyuluhan Akses Permodalan merupakan edukasi bagi peserta untuk mendapatkan permodalan dalam rangka pengembangan usaha.

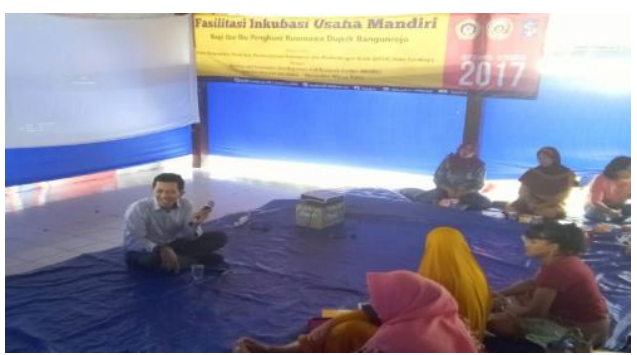

Gambar 8 Penyuluhan Akses Permodalan di Rusun Dupak

\section{Pendampingan Fasilitasi Inkubasi Usaha Mandiri}

Setelah rangkaian pelatihan selesai kemudian dilanjutkan dengan pendampingan. Pendampingan ini memfasilitasi peserta agar dapat konsultasi terkait hasil mereka mempraktekkan ilmu yang sudah diberikan pada beberapa pelatihan sebelumnya. Disamping menerima konsultasi para narasumber pendampingan juga memberikan tips dan trik untuk mengatasi permasalahan-permasalahan yang dihadapi peserta.

\section{Pendampingan Manajemen Produksi}

Pendampingan Manajemen Produksi merupakan waktu yang disediakan oleh narasumber untuk konsultasi terhadap permasalahanpermasalahan yang dihadapi oleh peserta saat melakukan proses produksi.

\section{Pendampingan Manajemen Pemasaran}

Pendampingan Manajemen Pemasaran bertujuan untuk menampung permasalahan pemasaran yang telah dilakukan oleh peserta pelatihan. Para narasumber pendampingan ini akan memberikan solusi terkait permasalahan tersebut. Bagi peserta yang penjualannnya sudah meningkat diberi kesempatan untuk berbagi pengalaman dalam melakukan penjualan produk sehingga dapat menjadi alternatif penyelesaian dari kendala pemasaran yang dihadapi peserta.

\section{Pendampingan Manajemen Keuangan}

Pendampingan Manajemen Keuangan bertujuan untuk memberikan pengarahan secara langsung kepada peserta yang masih kesulitan dalam membuat pencatatan keuangan. Bagi peserta yang sudah mampu membuat pencatatan juga dikoreksi hasilnya agar tidak terjadi kesalahan.

\section{Pendampingan Manajemen Organisasi dan SDM} Pendampingan Manajemen Organisasi dan SDM ini bertujuan agar peserta menyampaikan keberhasilan maupun kendala yang dihadapi dalam menjalankan usaha secara kelompok maupun individu. Para narasumber perlu memastikan kemampuan peserta dalam menerapkan ilmu tentang Manajemen Organisasi dan SDM dalam kelompoknya masing-masing

\section{Pendampingan Legalitas Usaha}

Pendampingan Legalitas Usaha ini bertujuan untuk mendampingi peserta dalam proses mempersiapkan mengurus legalitas. Diantaranya peserta didampingi dalam hal pembuatan label produk. Narasumber memberikan saran-saran agar Label Produk peserta memenuhi kriteria yang telah ditentukan.

\section{Pendampingan Lingkungan}

Pendampingan Lingkungan ini bertujuan agar peserta tetap memperhatikan kebersihan lingkungan

$$
\text { Ekonomi, Sosial dan Budaya }
$$

1455 
saat melakukan proses produksi. Kenyamanan lingkungan dan kebersihan lingkungan rusun harus tetap diperhatikan. Proses produksi tidak boleh menyebabkan lingkungan menjadi kotor dan tercemar oleh limbah usaha peserta Fasilitasi Inkubasi Usaha Mandiri.

\section{Pendampingan Akses Permodalan}

Pendampingan Akses Permodalan ini sebagai sarana untuk menerima konsultasi peserta terkait permodalan. Usaha yang baru dirintis tentunya lebih difokuskan pada modal yang sudah dimiliki oleh peserta berupa peralatan, Sumber Daya Manusia maupun modal berupa uang anggota kelompok usaha. Peserta diharapkan dapat memaksimalkan pemanfaatan modal yang sudah dimiliki untuk merintis usaha sebelum mereka memenuhi syarat untuk mengajukan pinjaman modal usaha kepada perbankkan.

\section{Identifikasi Penurunan Jumlah Peserta}

Pelatihan dan pendampingan Fasilitasi Inkubasi Usaha Mandiri secara umum berjalan baik dan lancar. Meskipun ada penurunan dari jumlah peserta yang mendaftar dengan peserta yang mengikuti pelatihan maupun pendampingan.

Beberapa narasumber melakukan identifikasi terhadap penyebab menurunnya kehadiran tersebut. Identifikasi dilakukan dengan cara menggali informasi dari peserta yang aktif melalui wawancara dan secara langsung mendatangi ke tempat peserta yang tidak aktif. Berikut ini beberapa faktor penyebabnya; 1). Bekerja, beberapa peserta terkendala untuk menghadiri pelatihan karena kerja. Semula mereka berharap pelatihan diadakan pada hari libur atau diluar jam kerja. Karena pelatihan dilaksanakan pada jam kerja sehingga mereka tidak dapat menghadiri pelatihan; 2) Mengasuh Anak atau Cucu, peserta yang sudah mendaftar dan terkendala harus mengasuh anaknya yang masih balita atau Nenek yang mengasuh cucunya karena orang tuanya bekerja juga tidak bisa aktif menghadiri pelatihan, diantaranya ada yg tidak pernah hadir pelatihan dan ada yang hadir hanya sekali; 3). Mengharap Uang Saku atau Modal, beberapa peserta mengharapkan dapat uang saku setiap mengikuti pelatihan atau bahkan mendapatkan modal usaha. Karena diawal diinformsikan bahwa tidak ada uang saku dan bantuan modal usaha maka beberapa peserta tidak hadir pada pelatihan-pelathan berikutnya; 4). Mengantar Sekolah, peserta yang memiliki anak sekolah masih kecil terutama usia Taman Kanak - Kanak (TK) harus mengantarkan sekolah bahkan menunggunya hingga jam pulang sekolah sehingga tidak dapat menghadiri pelatihan; 5). Faktor Lain, jumlah peserta yang menurun kehadirannya kemungkinan juga disebabkan faktorfaktor lain yang belum teridentifikasi. Kemungkinan faktor-faktor lain tersebut diantaranya karena malas, kurang motivasi, kurang berminat dan lainnya.

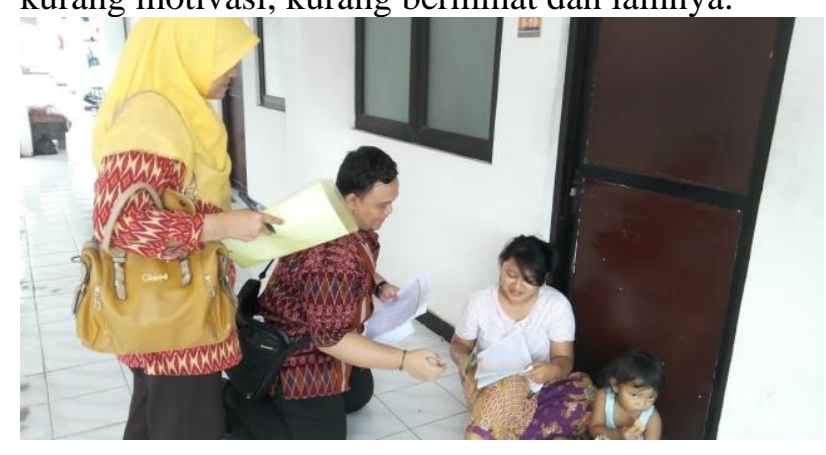

Gambar 9 Proses Pendampingan Usaha Hasil Pelatihan dan Pendampingan

Peserta Pelatihan Fasilitasi Inkubasi Usaha Mandiri diharapkan mampu mulai melakukan produksi dan memasarkan produknya. Peserta dibimbing untuk memulai mencari konsumen baik perorangan maupun toko, warung, koperasi dan tempat lainnya yang dapat membantu menjualkan produk peserta.

\section{Hasil Awal Produksi}

Peserta mulai melakukan produksi pada minggu pertama setelah mengikuti pelatihan keterampilan membuat Brownies Kering dan Kerupuk Aneka Rasa berbahan singkong. Peserta praktek secara kelompok dan ada yang secara perorangan sesuai Pelatihan Kerampilan yang mereka pilih. Praktek pertama hasilnya masih belum memiliki nilai jual terutama dari segi bentuk namun beberapa kelompok sudah dapat memproduksi Brownies Kering atau Kerupuk dengan Rasa yang sudah layak jual

\section{Hasil Praktek Produksi Siap Jual}

$$
\text { Ekonomi, Sosial dan Budaya }
$$


Peserta berusaha memproduksi dengan hasil yang layak jual melalui beberapa kali percobaan produksi dengan resep kecil untuk mengurangi biaya. Setelah beberapa kali produksi akhirnya mereka mampu membuat produk yang siap untuk dijual.

Peserta bersemangat memperkenalkan produknya masing-masing kepada masyarakat. Kelompok yang aktif cepat mendapatkan konsumen dan pelanggan. Sementara kelompok yang masih ragu menawarkan belu, negitu banyak mendapatkan konsumen. Berikut beberapa dokumentasi produk dan konsumen peserta Fasilitasi Inkubasi Usaha Mandiri

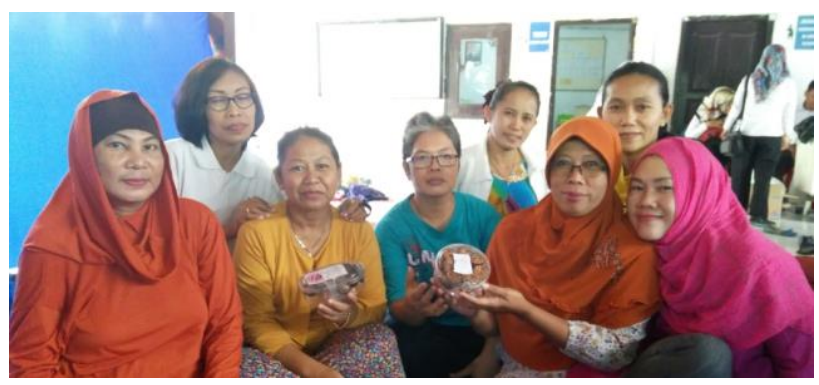

Gambar 10 Hasil produksi peserta

\section{Peserta Berlomba Mendapatkan Konsumen}

Peserta bersemangat memperkenalkan produknya dan hasilnya sangat memuaskan bagi yang mampu bekerja sama dengan baik dengan anggota kelompoknya sehingga omsetnya terus meningkat. Beberapa peserta tidak menunjukkan pencatatan hasil penjualannya karena merasa penjualannya masih sangat rendah. Diantara peserta juga ada yang ikut pelatihan karena ingin mendapatkan ilmu untuk mengembangkan usaha yang sudah dimilikinya sehingga tidak ikut praktek memulai usaha membuat Brownies Kering maupaun Kerupuk Aneka Rasa.

\section{KESIMPULAN}

Program Fasilitasi Inkubasi Usaha Mandiri ini terdiri dari kegiatan beberapa pelatihan dan pendampingan. Adapun beberapa pelatihan yang telah diberikan kepada peserta terdapat tujuh jenis pelatihan yaitu : 1). Pelatihan Motivasi Wirausaha; 2). Pelatihan Keterampilan; 3). Pelatihan Manajemen Pemasaran; 4). Pelatihan Manajemen Keuangan; 5). Pelatihan Manajemen Organisasi dan SDM; 6).
Penyuluhan Legalitas Usaha dan Lingkungan dan 7). Penyuluhan Akses Permodalan

Setelah rangkaian pelatihan selesai kemudian dilanjutkan dengan pendampingan. Pendampingan ini memfasilitasi peserta agar dapat konsultasi terkait hasil mereka mempraktekkan ilmu yang sudah diberikan pada beberapa pelatihan sebelumnya. Disamping menerima konsultasi para narasumber pendampingan juga memberikan tips dan trik untuk mengatasi permasalahanpermasalahan yang dihadapi peserta. Adapun jenis pendampingan yaitu : 1). Pendampingan Manajemen Produksi; 2). Pendampingan Manajemen Pemasaran; 3). Pendampingan Manajemen Keuangan; 4). Pendampingan SDM; 5). Pendampingan Legalitas Usaha; 6). Pendampingan Lingkungan; dan 7). Pendampingan Akses Permodalan

Peserta Inkubasi Bisnis ini sangat antusias. Rata-rata mereka yang hadir mengkuti proses pelatihan maupun pendampingan dari awal sampai akhir tidak ada yang pulang sebelum acara selesai kecuali yang ada kepentingan seperti menjemput anak atau mau ke dokter. Beberapa manfaat yang diperoleh peserta berdasarkan pengamatan naraumber, kesaksian peserta maupun informasi dari ketua paguyuban rusun, yaitu : 1 . Peserta memiliki motivasi untuk meningkatkan perekonomian keluarganya sehingga bersedia mengikuti program inkubasi ini; 2. Peserta mampu memulai mengembangkan jaringan distribusinya terbukti meningkatnya omset beberapa kelompok karena mendapat pelanggan baru; 3. Penghuni Rusun memiliki kegiatan produktif yang menghasilkan uang sehingga membuat mereka lebih bersemangat; 4. Berkurangnya kegiatan tidak produktif dilingkungan rusun karena beberapa diantaranya menjadi sibuk produksi dan memasarkan produknya; 5. Kreatifitas peserta meningkat terbukti dengan meningkatnya kelayakkan kemasan produk, label dan kualitas produk; 6. Peserta mampu mempraktekkan ilmu yang diperolehnya dari rangkaian beberapa pelatihan dan pendampingan Inkubasi Bisnis ini, terbukti mereka mampu memperoleh omset ratusan ribu hingga jutaan rupiah.

Secara umum Pelatihan dan pendampingan Fasilitasi Inkubasi Usaha Mandiri berjalan baik dan lancar. Meskipun ada penurunan dari jumlah peserta yang mendaftar dengan peserta yang mengikuti pelatihan maupun pendampingan. Beberapa

$$
\text { Ekonomi, Sosial dan Budaya }
$$


narasumber melakukan identifikasi terhadap penyebab menurunnya kehadiran tersebut. Identifikasi dilakukan dengan cara menggali informasi dari peserta yang aktif melalui wawancara dan secara langsung mendatangi ke tempat peserta yang tidak aktif. Berikut ini beberapa faktor penyebabnya : 1). Bekerja, beberapa peserta terkendala untuk menghadiri pelatihan karena kerja. Semula mereka berharap pelatihan diadakan pada hari libur atau diluar jam kerja. Karena pelatihan dilaksanakan pada jam kerja sehingga mereka tidak dapat menghadiri pelatihan; 2). Mengasuh Anak atau Cucu, peserta yang sudah mendaftar dan terkendala harus mengasuh anaknya yang masih balita atau Nenek yang mengasuh cucunya karena orang tuanya bekerja juga tidak bisa aktif menghadiri pelatihan, diantaranya ada yg tidak pernah hadir pelatihan dan ada yang hadir hanya sekali; 3). Mengharap Uang Saku atau Modal, beberapa peserta mengharapkan dapat uang saku setiap mengikuti pelatihan atau bahkan mendapatkan modal usaha. Karena diawal diinformsikan bahwa tidak ada uang saku dan bantuan modal usaha maka beberapa peserta tidak hadir pada pelatihan-pelatihan berikutnya; 4). Mengantar Sekolah, peserta yang memiliki anak sekolah masih kecil terutama usia Taman Kanak Kanak (TK) harus mengantarkan sekolah bahkan menunggunya hingga jam pulang sekolah sehingga tidak dapat menghadiri pelatihan; dan 5). Faktor Lain, jumlah peserta yang menurun kehadirannya kemungkinan juga disebabkan faktor-faktor lain yang belum teridentifikasi. Kemungkinan faktorfaktor lain tersebut diantaranya karena malas, kurang motivasi, kurang berminat dan lainnya.

Pada dasarnya setiap peserta yang memulai usaha secara individu maupun secara berkelompok sudah mampu bekerja sama dan memiliki toleransi yang baik. Meskipun terdapat sedikit permasalahan yang timbul namun secara umum tidak begitu mengganggu proses usaha peserta. Adapun permasalahan-permasalahan yang timbul yaitu; 1).
Persaingan Kurang Sehat, terdapat kelompok sesama produksi Kerupuk yang menghambat kelompok lain dengan cara mengganggu proses produksi kelompok lain yang dianggap lebih cepat meningkat omsetnya; 2). Konflik Internal Kelompok Usaha, munculnya masalah pada beberapa kelompok usaha yang belum mampu membangun kerja sama yang baik dalam kelompoknya. Sehingga terdapat anggota yang kurang aktif namun menginginkan hasil dari usaha kelompoknya. Atau terdapat anggota yang memaksakan kehendak karena belum terbiasa bekerja secara tim sehingga menimbulkan ketidaknyamanan anggota lain; 3). Aktif Tapi Pasif, terdapat sedikit peserta yang aktif mengikuti pelatihan hingga pendampingan namun sangat kurang dalam mempraktekkan ilmu yang sudah diberikan sehingga penghasilannya tidak ada peningkatan; dan 4). Kendala Alat Produksi, untuk memulai usaha ini peserta membutuhkan bahan baku dan alat untuk produksi. Harga alat yang lebih mahal dibanding bahan baku yang dibutuhkan menjadi kendala tersendiri. Namun demikian dapat diatasi dengan memanfaatkan alat seadanya yang dimiliki oleh anggota kelompok usaha atau pinjam kepada saudara dan pada akhirnya mereka mampu membeli dari hasil usaha yang mulai menghasilkan omset.

\section{UCAPAN TERIMAKASIH}

Ucapan terimakasih disampaikan kepada Dinas Pengendalian Penduduk, Pemberdayaaan Perempuan, Perlindungan Anak Kota Surabaya, Lembaga Penelitian dan Pengabdian kepada Masyarakat Universitas Wijaya Putra, Fakultas Ekonomi dan Bisnis Universitas Wijaya Putra dan Pusat Pengembangan dan Penelitian Ekonomi dan Bisnis (BEDRC) FEB-UWP.

\section{REFERENSI}

Ekonomi, Sosial dan Budaya 